Brit. F. industr. Med., 1968, 25, 165.

\title{
Chronic Respiratory Disease in Mining Communities in Marion County, West Virginia
}

\author{
I. T. T. HIGGINS 1 , M. W. HIGGINS 1 , M. D. LOCKSHIN ${ }^{2}$, and N. CANALE \\ From the Department of Epidemiology and Microbiology, Graduate School of Public Health, \\ University of Pittsburgh, Pittsburgh, Pennsylvania
}

A study of respiratory disease has been carried out in five mining communities in Marion County, West Virginia, United States of America. Each of the five communities was defined by a private census. A questionnaire on respiratory symptoms, chest and other illnesses, smoking habits, and occupation was completed on all adults aged 20 years and over. All men aged 20-69 who lived in three of the towns were asked to attend at a centre for examination and $83 \%$ responded. The examination included the completion of a further questionnaire on respiratory symptoms, occupation, and smoking habits; examination of the chest; simple tests of ventilatory lung function; and a I $4 \times 17$ in. postero-anterior radiograph of the chest.

The prevalence of pneumoconiosis in these communities was low. In one of the three towns a pottery had operated intermittently in the past, giving rise to the possibility of pottery as well as mine dust exposure. Approximately 10-15\% of miners and ex-miners aged 50-69 who had never worked in the pottery had category I or over pneumoconiosis. Only four cases of progressive massive fibrosis were found in this group, all in men aged 60 years and over. Pneumoconiosis was diagnosed only in men who had worked for 20 years or more underground. Among a group of potters who had never worked in mining the prevalence of pneumoconiosis was higher than in the miners and ex-miners, $27 \%$ in the $50-59$ age group and $18 \%$ in the $60-69$ age group being affected.

The prevalence of symptoms was not appreciably higher in the miners and the ex-miners than in the non-miners except in the oldest decennial group where a somewhat higher prevalence of cough, breathlessness, and chest illness was noted. A significantly lower average forced expiratory volume in one second (F.E.V.1.0 ) was also found in this group. A higher prevalence of breathlessness, chest illness, and chronic bronchitis was found in non-miners who had worked in the pottery, and this increased prevalence was associated with a lower mean F.E.V.1.0.

Smokers recorded a higher prevalence of symptoms, particularly cough and sputum, than non-smokers. Significantly lower mean F.E.V.1.0 values were found in smokers than in non-smokers aged 50 years and over. There was an association between the educational level attained and both the prevalence of symptoms and the F.E.V.1.0. Those with lower educational grades had a significantly higher prevalence of symptoms, especially cough and sputum. Those who had completed one year or more in college recorded higher F.E.V.s. These differences are the subject of further study.

Differences in the prevalence of persistent cough, sputum or breathlessness between communities studied in the United States and the United Kingdom are small or absent. Bronchitic chest illnesses during the three years before interview, particularly those which recurred, appear however to be more common in Britain, and this may explain at least partly the greater disability and mortality from chronic respiratory disease in the United Kingdom than in the United States.

Death rates suggest that chronic respiratory disease is increasing in importance in the United States (Moriyama, 1963; Dorn, 1961). There has been a uniform increase in the rates for the category emphysema without mention of bronchitis (International Statistical Classification 527.I) in both men and women and a smaller increase for bronchitis

Presented at the A.P.H.A. Environmental Epidemiology Session October 25, 1967.

Received for publication January 10, 1968.
(I.S.C. 500-502) in men between 1950 and 1964 (Vital Statistics of United States 1950-64). Similar

\footnotetext{
1Present address: Department of Epidemiology, School of Public Health, University of Michigan, Ann Arbor, Michigan 48104.

${ }^{2}$ Dr. M. D. Lockshin's work on this project was carried out during the course of his assignment as an Epidemic Intelligence Service Officer of the U.S. Public Health Service.
} 
trends have been noted in certain states (Merrill, 1963) and cities (Densen, Brewer, Bass, and Jones, 1966). How much such an increase in death rates is due to fashions in death certification is uncertain. The fact that the trend for emphysema appears to have affected men and women and white and nonwhite equally suggests that much of the increase is more apparent than real.

The rates for certain categories of respiratory disease in the United States are much lower than in the United Kingdom, where chronic respiratory disease has long been recognized as a serious problem. Comparisons based on deaths certified as due to bronchitis (I.S.C. 500-502) are, however, misleading because of the vagaries of classification of respiratory diseases in different countries. A truer appreciation of international differences can be obtained only when all the categories are considered. If the United States and the United Kingdom are compared, the difference in bronchitis rates is approximately 25 -fold; but the difference for all respiratory disease is roughly three-fold (Vital Statistics of United States, 1963; Registrar General, 1965; World Health Organization, 1963).

One of the more striking differences in respiratory disease death rates for the United States is in relation to occupation (Enterline, 1966). Mine operatives and labourers have particularly high rates. In the United Kingdom, bronchitis death rates are high in coal miners though these are only about $30 \%$ above the average compared with the nine-fold higher rates in the United States (Vital Statistics of 1963; Registrar General, 1958).

A number of studies of the relation of occupation to chronic respiratory disease and ventilatory lung function have been carried out in Britain (Higgins, Oldham, Cochrane, and Gilson, 1956; Higgins, Cochrane, Gilson, and Wood, 1959; Higgins and Cochrane, 196I; Higgins and Oldham, 1962). Representative samples of miners and ex-miners were compared with non-miners of similar age living in the same area. Respiratory symptoms and smoking habits were recorded in a standardized manner, and simple tests of ventilatory lung function were applied. These studies supported conclusions based on mortality that miners had more disabling respiratory disease than non-miners. They also suggested that the effect of mining differed in different areas.

In 1963 the U.S. Public Health Service initiated a population-based investigation of two mining communities in southern West Virginia. The main aim of these studies was to compare respiratory symptom prevalence and ventilatory lung function in miners and non-miners living in the same area, as had been done in the British studies. In view of probable differences in the effect on health of mining in different areas, further studies seemed desirable. The present study was undertaken to fill this need and to obtain comparable information for mining communities in northern West Virginia. An additional aim was the identification of other factors related to the development and progress of chronic respiratory disease by means of national and international comparisons.

\section{Methods and Procedure}

Choice of Community A community-based comparison of miners and non-miners requires approximately equal numbers of men in mining and in other jobs. The number of working miners in each county in Pennsylvania and West Virginia was therefore related to the total population of each county. Of those counties having a relatively high proportion of miners to the total population, Marion County in northern West Virginia was eventually selected as the most suitable. It is approximately Ioo miles from Pittsburgh and therefore was conveniently accessible to the investigators. Five towns in the county were selected because suitable proportions of their inhabitants worked or had worked in mining. These towns were Grant Town, Ida May, Mannington, Farmington, and Fairview. On the basis of the 1960 census, the total population was about 6,000 inhabitants.

The Census Every house in each town was visited by a home visitor, who obtained basic demographic information for each member of the household and completed a household form. A questionnaire on respiratory symptoms, previous chest and other illnesses, previous admissions to hospital, educational attainment, occupation, and smoking habits was completed for all adults aged 20 years and over. The questions on respiratory symptoms, chest illnesses, occupation, and smoking habits were basically similar to those used in the Medical Research Council's respiratory symptom questionnaire (I960).

Examination of the Men All men aged 20-69 from three of the five towns were invited to attend by appointment at a centre for a medical interview, physical examination, and a number of special investigations. The items in the examination which are relevant to this paper were:

I. a questionnaire about respiratory symptoms, chest illnesses, and smoking habits;

2. an occupational history from the time of leaving school;

3. a clinical examination of the chest and joints;

4. measurement of standing and sitting heights to the nearest centimetre and of weight to the nearest kilogram;

5. measurement of the one-second forced expiratory volume (F.E.V.1.0) and forced vital capacity (F.V.C.) 
using a Poulton spirometer (McKerrow, McDermott, and Gilson, I960). The mean of three readings after a practice blow was taken corrected to B.T.P.S.;

6. a postero-anterior $\mathrm{I}_{4} \times \mathrm{I}_{7} \mathrm{in}$. radiograph of the chest, P.A. of hands, and lateral of the cervical spine;

7. a I2-lead resting electrocardiogram;

8. measurement of the first-hour sputum volume and classification of sputum quality. Each man was asked to collect in the bottle provided all the sputum he brought up in the first hour after rising.

The chest radiographs were read for clinically significant disease during the course of the survey. When the examinations were completed for all three towns, the chest radiographs were read systematically for pneumoconiosis and other conditions by one observer (I.T.T.H.). The International Labour Organization's Classification (1958) for pneumoconiosis was used. The E.C.G.s were read clinically during the survey and classified according to the Minnesota Code (Blackburn, Keys, Simonson, Rautaharju, and Punsar, I960) afterwards.

\section{Results}

Response Rates There were 5,540 persons living in the five towns, 2,675 men and 2,865 women. Five thousand three hundred and thirtyeight were white and 202 were non-white. One thousand five hundred and twenty-two $(94.3 \%)$ of the white men and $1,704(92 \cdot 7 \%)$ of the white women who were aged 20 years and over were interviewed. But only $45(75.0 \%)$ of the non-white men and $45(77.6 \%)$ of the none-white women aged 20 and over were interviewed. The examination response rate for men aged $20-69$ is shown by race and occupation in Table I. Eighty-four per cent of the white men but only $61 \%$ of the non-white participated. Nearly all the Negroes lived in one town where the response rate was poor, partly because of the fear that unhealthy miners would lose their jobs. This is also reflected in the slightly lower response rates for white miners compared with ex-miners and non-miners.

\section{Prevalence of Pneumoconiosis}

Mining Thirty-six (7.5\%) miners or ex-miners were found to have radiological changes classified as pneumoconiosis category I or more. In one of the three towns a pottery had operated intermittently in the past, though at the time of the survey it had closed permanently. Ninety-eight men, 35 miners and ex-miners and 63 non-miners, had worked for varying periods in the pottery and of these 94 were $x$-rayed. There were three cases of pneumoconiosis among the miners and ex-miners and eight cases among the non-miners who had worked in pottery dust. In order to get a clear idea of the effect of mining in causing pneumoconiosis, the prevalence in miners and ex-miners who had never worked in the pottery is shown in Table II. The prevalence is low particularly in those under 50 years of age. No cases were found in men under 40 years. Only four cases of progressive massive fibrosis (P.M.F.) were found, two in whites and two in Negroes. All

TABLE II

Prevalence of PNeumoconiosis in Miners aNd EX-Miners Aged 20-69 IN Three TOWNS IN MARION COUNTY, WEST VIRGINIA

(White AND NoN-White without PotTery ExperienCE)

\begin{tabular}{|c|c|c|c|c|c|}
\hline \multirow{2}{*}{$\begin{array}{c}\text { Age } \\
\text { Group }\end{array}$} & \multirow{2}{*}{$\begin{array}{c}\text { No. } \\
\text { X-rayed }\end{array}$} & \multicolumn{4}{|c|}{ Pneumoconiosis } \\
\hline & & Simple & P.M.F. & No. & al \\
\hline $20-$ & 15 & 0 & 0 & 0 & - \\
\hline $30-$ & 62 & 0 & 0 & 0 & - \\
\hline $40-$ & 139 & 2 & o & 2 & $\mathrm{I} \cdot 4$ \\
\hline $50-$ & 145 & 21 & 0 & 21 & 14.5 \\
\hline $60-$ & 87 & 6 & 4 & 10 & II. 5 \\
\hline All ages & 448 & 29 & 4 & 33 & $7 \cdot 4$ \\
\hline
\end{tabular}

TABLE I

Response Rates by Occupation and Race in Men Aged 20-69 in Three Towns in Marion County, West Virginia

\begin{tabular}{|c|c|c|c|c|c|c|c|c|c|c|c|}
\hline \multirow{2}{*}{\multicolumn{3}{|c|}{ Occupation }} & \multicolumn{3}{|c|}{ Available } & \multicolumn{6}{|c|}{ Examined } \\
\hline & & & \multirow{2}{*}{$\begin{array}{c}\text { White } \\
399 \\
161 \\
546\end{array}$} & \multirow{2}{*}{$\begin{array}{c}\text { Non-white } \\
32 \\
12 \\
7\end{array}$} & \multirow{2}{*}{$\begin{array}{c}\text { Total } \\
431 \\
73 \\
553\end{array}$} & \multicolumn{2}{|c|}{$\begin{array}{l}\text { White } \\
\text { No. } \%\end{array}$} & \multicolumn{2}{|c|}{$\begin{array}{l}\text { Non-white } \\
\text { No. } \quad \%\end{array}$} & \multicolumn{2}{|c|}{ No. ${ }^{\text {Total }} \%$} \\
\hline $\begin{array}{l}\text { Miners ... } \\
\text { Ex-miners } \\
\text { Non-miners }\end{array}$ & $\begin{array}{l}. . \\
\cdots \\
\cdots\end{array}$ & $\begin{array}{l}. \\
\cdots \\
\cdots\end{array}$ & & & & $\begin{array}{l}324 \\
137 \\
465\end{array}$ & $\begin{array}{l}8 \mathrm{I} \cdot 2 \\
85 \cdot 1 \\
85 \cdot 2\end{array}$ & $\begin{array}{r}14 \\
11 \\
6\end{array}$ & $\begin{array}{l}43 \cdot 8 \\
91 \cdot 7 \\
85 \cdot 7\end{array}$ & $\begin{array}{l}338 \\
148 \\
471\end{array}$ & $\begin{array}{l}78 \cdot 4 \\
86 \cdot 6 \\
85 \cdot 2\end{array}$ \\
\hline Total & . & . & I,106 & 51 & I,I 57 & 926 & $83 \cdot 7$ & $3 I$ & $60 \cdot 8$ & 957 & $82 \cdot 7$ \\
\hline
\end{tabular}


four were men aged 60-90, who had worked for over 30 years underground.

In previous studies in Britain two indices of dust exposure have been used: (I) the number of years spent working underground; and (2) the number of years spent working at the coal face on the coalgetting shift. Of the two, the second is perhaps best related to the lifetime dust dosage to which a man has been exposed. In the United States the methods of mining are sufficiently different to make such a clear differentiation of face work and other work less meaningful. Certain jobs off the face may be as dusty or even more dusty than face work. For example, the occupation of motorman may involve a significant exposure to silica dust due to sand which is put on the rails to produce adequate friction and so prevent the wheels of the tubs from slipping.

The prevalence of pneumoconiosis in white and non-white miners and ex-miners aged 20-69 by duration of underground work is shown in Table III.

\section{TABLE III}

Prevalence of Pneumoconiosis by Number of Years UNDERGROUND IN MINERS AND EX-MINERS AGED 20-69 in Three Towns in Marion County, West Virginia (WhITE AND NoN-White WITHOUt POTTERY EXPERIENCE)

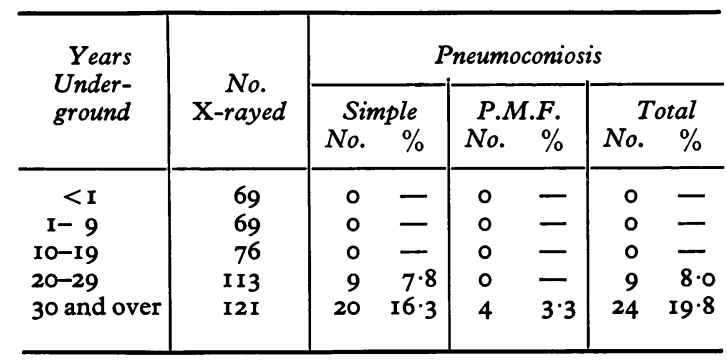

Only those men who had worked underground for 20 years and more were found to have radiological changes. P.M.F. occurred only after exposures of 30 years or longer. One of the four men with P.M.F. had worked for 36 years underground as a hand loader, two others had spent 49 years underground, one as a hand loader, driller and shot firer, and roof bolter and the other as motorman and brakeman. The fourth man had worked underground for 37 years as a loader, shot firer, roof bolter, and timberman.

Pottery Work The prevalence of pneumoconiosis in men who had worked in the pottery but never in the mines is shown in Table IV Eight had
TABLE IV

Prevalence of Pneucomoconiosis in Potters Aged 20-69 in Three Towns in Marion County, West Virginia (WHITE AND NON-WHITE NON-MINERS)

\begin{tabular}{|c|c|c|c|c|c|c|}
\hline \multirow{2}{*}{$\begin{array}{c}\text { Age } \\
\text { Group }\end{array}$} & \multirow{2}{*}{$\begin{array}{c}\text { No. } \\
\text { Examined }\end{array}$} & \multirow{2}{*}{$\begin{array}{c}\text { No. } \\
\mathrm{X} \text {-rayed }\end{array}$} & \multicolumn{4}{|c|}{ Pneumoconiosis } \\
\hline & & & $\begin{array}{r}\text { Simple } \\
\text { No. } \%\end{array}$ & $\begin{array}{l}\text { P.M.F. } \\
\text { No. } \%\end{array}$ & $\begin{array}{r}T \\
\text { No. }\end{array}$ & $\begin{array}{r}\text { tal } \\
\%\end{array}$ \\
\hline $20-$ & $\mathbf{I}$ & I & 0 & 0 & 0 & - \\
\hline $30-$ & 13 & 12 & 0 & 0 & 0 & - \\
\hline $40-$ & 15 & 15 & 0 & 0 & 0 & - \\
\hline $50-$ & 23 & 22 & $18 \cdot 2$ & $9 \cdot I$ & 6 & $27 \cdot 3$ \\
\hline $60-$ & II & II & I $\quad 9 \cdot$ I & $9 \cdot I$ & 2 & $18 \cdot 2$ \\
\hline $20-69$ & 63 & $6 I$ & $8 \cdot 2$ & 4.9 & 8 & $13 \cdot 1$ \\
\hline
\end{tabular}

radiological changes, of whom three had P.M.F. The prevalence of pneumoconiosis by duration of pottery work is shown in Table V. Though the numbers are small the findings suggest a considerable risk of pneumoconiosis after a relatively short exposure.

\section{TABLE V}

Prevalence of Pneumoconiosis by Number of Years in Pottery in Non-miners Aged 20-69 in Three Towns IN MARION COUNTY, West Virginia (WHITE AND NON-WHITE NON-MINERS)

\begin{tabular}{|c|c|c|c|c|c|c|c|}
\hline \multirow{2}{*}{$\begin{array}{c}\text { Years } \\
\text { in } \\
\text { Pottery }\end{array}$} & \multirow{2}{*}{$\begin{array}{c}\text { No. } \\
\text { X-rayed }\end{array}$} & \multicolumn{6}{|c|}{ Pneumoconiosis } \\
\hline & & & & $\begin{array}{l}\text { P.N } \\
\text { No. }\end{array}$ & & $\begin{array}{r}T \\
N o .\end{array}$ & tal \\
\hline$<$ I & 5 & o & 一 & o & - & o & 0 \\
\hline$I-9$ & 27 & 0 & 一 & I & $3 \cdot 7$ & $\mathbf{I}$ & $3 \cdot 7$ \\
\hline 10-19 & 16 & 0 & - & I & $6 \cdot 3$ & I & $6 \cdot 3$ \\
\hline $20-29$ & 8 & 3 & $37 \cdot 5$ & I & $12 \cdot 5$ & 4 & $50 \cdot 0$ \\
\hline 30 and over & 5 & 2 & $40 \cdot 0$ & 0 & - & 2 & $40 \cdot 0$ \\
\hline
\end{tabular}

Prevalence of Respiratory Symptoms and Measurements of Ventilatory Lung Function The definitions of cough, sputum, and chest illness are similar to those used previously. Thus, cough and sputum were present most days for at least three months out of the year and a chest illness was one with cough and sputum and incapacity for one week. The definition of breathlessness was slightly different from that used in earlier studies. Moderate (grade 3) means 'short of breath when walking with others on the level', severe (grade 4) means 'has to stop after about roo yards on the level'.

Age-adjusted prevalence rates for respiratory symptoms are given for men in different occupations 
TABLE VI

Prevalence of Respiratory Symptoms by Age aNd Occupation in White Men Aged 20-69 In Three TOWNS IN MARION COUNTY, WeSt VIRGINIA (Age-Adjusted Percentages)

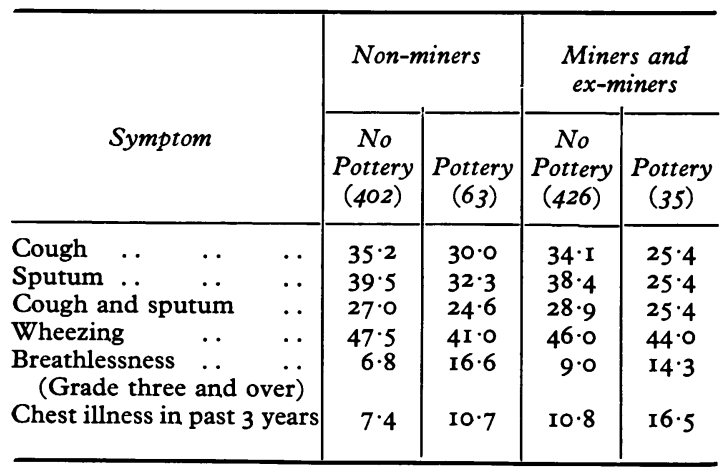

Numbers in parentheses.

in Table VI. The differences are not large. Miners and ex-miners without pottery experience reported breathlessness and chest illness more often than the comparable group of non-miners, but even the difference for chest illness fails to reach statistical significance (0.10> $>>0.05)$. Comparisons within age-specific groups ${ }^{1}$ showed that cough, moderate and severe breathlessness, and chest illness were more common among miners and ex-miners than

\section{TABLE VII}

MEAN F.E.V.1.0 (LITRES) By Age AND OCCUPATION IN White Men Aged 20-69 IN Three Towns IN Marion County, West Virginia

\begin{tabular}{c|c|c|c|c}
\hline \multirow{2}{*}{$\begin{array}{c}\text { Age } \\
\text { Group }\end{array}$} & \multicolumn{2}{|c|}{ Non-miners } & \multicolumn{2}{c}{ Miners and Ex-miners } \\
\cline { 2 - 4 } & $\begin{array}{c}\text { No Pottery } \\
\text { (399) }\end{array}$ & $\begin{array}{c}\text { Pottery } \\
(62)\end{array}$ & $\begin{array}{c}\text { No Pottery } \\
(425)\end{array}$ & $\begin{array}{c}\text { Pottery } \\
(33)\end{array}$ \\
\hline $20-$ & 4.33 & 4.72 & 4.30 & - \\
$30-$ & 4.07 & 3.80 & 3.91 & 3.98 \\
$40-$ & 3.60 & 3.57 & 3.56 & 3.91 \\
$50-$ & 2.98 & 2.96 & 2.96 & 3.04 \\
$60-69$ & $2.78^{1}$ & $2.45^{2}$ & $2 \cdot 37^{1}$ & $2 \cdot 70^{2}$ \\
\hline
\end{tabular}

Numbers in parentheses.

${ }^{1}$ Difference between miners and ex-miners and non-miners without pottery experience signficant $(\mathrm{P}<0.00 \mathrm{I})$.

${ }^{2}$ Difference between miners and ex-miners and non-miners with pottery experience not significant $(P>0.35)$.

${ }^{1}$ Additional tabulations are available on request from Dr. I. T. T. Higgins, Department of Epidemiology, School of Public Health, The University of Michigan, Ann Arbor, Michigan 48104. among non-miners at ages 60-69 years. Pottery workers reported breathlessness and chest illness more often but cough, sputum, and wheeze less often than non-potters, but again the differences are insignificant and the small number of potters precludes firm conclusions.

Mean values of F.E.V.1.0 are given by age and occupation in Table VII. In the absence of pottery work, miners and ex-miners aged 60-69 had significantly lower values than non-miners of the same age. This difference was still apparent when men with pneumoconiosis were excluded. The relationship between ventilatory lung function and pottery exposure is not consistent, possibly because of small numbers. Differences between the occupational groups in symptom prevalence and the level of ventilatory lung function cannot be ascribed to differences in smoking habits or height for no such differences were found.

Relation of Respiratory Symptoms and F.E.V. to Duration of Underground Work We have looked into the prevalence of respiratory symptoms and mean values of F.E.V.1.0 by age and duration of underground work. Among miners and ex-miners aged 40-69, the prevalence of sputum and of breathlessness was higher in those who had worked for 30 years or more underground, and these men also tended to record a lower average F.E.V.1.0. Otherwise there were only inconsistent differences in symptom prevalence or F.E.V $\cdot_{1 \cdot 0}$ according to the duration of underground work.

Tobacco Smoking Smoking habits were recorded at the time the census information was collected. Any major changes between the census and the time of examination were recorded when the interval between the two exceeded one month. Persons were classified as non-smokers, current smokers, and ex-smokers. A non-smoker is defined, as in previous studies, as one who has never smoked as much as one cigarette (or an equivalent amount of tobacco) a day for a year. An ex-smoker is one who gave up smoking one month or more previously. Current smokers of cigarettes have been differentiated from smokers of pipes and cigars and classified according to the amount smoked, into smokers of I-I4, 15-24, and 25 and more cigarettes per day.

The age-adjusted prevalence of respiratory symptoms by smoking class is given for examined men in Table VIII. The prevalence of cough, sputum, and of cough and sputum was considerably higher in cigarette smokers than in other men. The prevalence of moderate and severe breathlessness 
TABLE VIII

Prevalence of Symptoms by Smoking Habits in White Men aged 20-69 in Three Towns in West Virginia (Age-Adjusted Percentages)

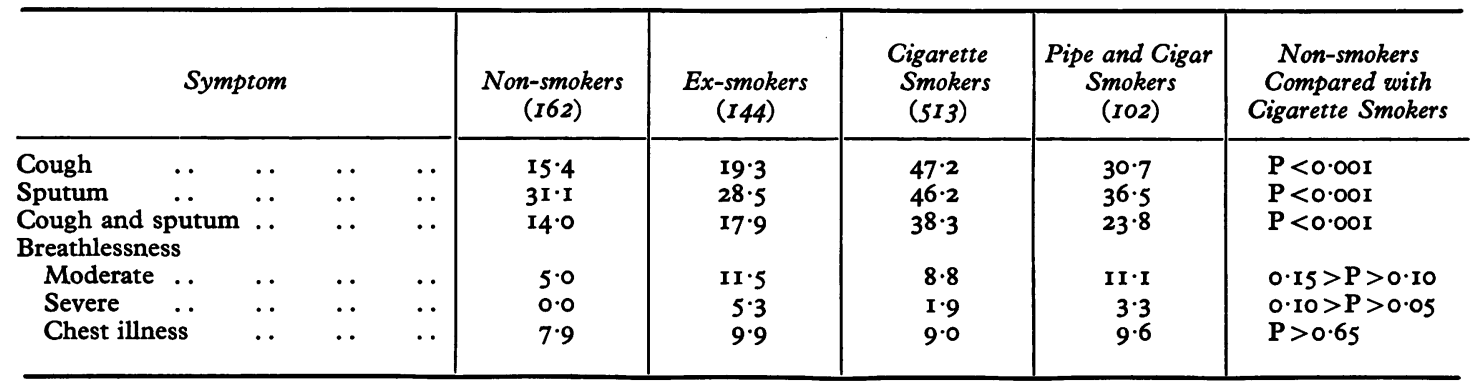

Numbers in parentheses.

TABLE IX

Mean F.E.V.1.0 (LITRES) by Age and SMoking Habits In White MEN In Three Towns In Marion County, West VIRGINIA

\begin{tabular}{|c|c|c|c|c|c|c|c|c|c|c|c|c|c|c|c|}
\hline \multirow[b]{2}{*}{ Age } & \multirow{2}{*}{\multicolumn{2}{|c|}{ Non-smokers }} & \multirow{2}{*}{\multicolumn{2}{|c|}{ Ex-smokers }} & \multicolumn{8}{|c|}{ Cigarette Smokers } & & & \multirow{2}{*}{$\begin{array}{l}\text { Non-smokers } \\
\text { Compared with } \\
\text { all Cigarette } \\
\text { Smokers }\end{array}$} \\
\hline & & & & & \multicolumn{2}{|c|}{$I-I 4$} & \multicolumn{2}{|c|}{$15-24$} & \multicolumn{2}{|c|}{$25+$} & \multicolumn{2}{|c|}{$\begin{array}{c}\text { Total } \\
\text { Cigarette } \\
\text { Smokers } \\
\text { No. Mean }\end{array}$} & \multicolumn{2}{|c|}{$\begin{array}{c}\text { Other } \\
\text { Smokers }\end{array}$} & \\
\hline $\begin{array}{l}20- \\
30- \\
40- \\
50- \\
60-\end{array}$ & $\begin{array}{l}38 \\
27 \\
29 \\
34 \\
32\end{array}$ & $\begin{array}{l}4 \cdot 32 \\
4 \cdot 12 \\
3 \cdot 53 \\
3 \cdot 35 \\
2 \cdot 82\end{array}$ & $\begin{array}{r}7 \\
18 \\
36 \\
44 \\
38\end{array}$ & $\begin{array}{l}4 \cdot 49 \\
3 \cdot 91 \\
3 \cdot 73 \\
3 \cdot 15 \\
2 \cdot 39\end{array}$ & $\begin{array}{r}15 \\
22 \\
22 \\
20 \\
9\end{array}$ & $\begin{array}{l}4 \cdot 33 \\
4 \cdot 16 \\
3 \cdot 77 \\
2 \cdot 99 \\
2 \cdot 61\end{array}$ & $\begin{array}{l}56 \\
55 \\
66 \\
72 \\
24\end{array}$ & $\begin{array}{l}4 \cdot 47 \\
3 \cdot 93 \\
3 \cdot 44 \\
2 \cdot 87 \\
2 \cdot 43\end{array}$ & $\begin{array}{l}21 \\
28 \\
42 \\
41 \\
18\end{array}$ & $\begin{array}{l}4 \cdot 02 \\
3 \cdot 91 \\
3 \cdot 56 \\
2 \cdot 61 \\
2 \cdot 44\end{array}$ & $\begin{array}{r}92 \\
105 \\
130 \\
133 \\
51\end{array}$ & $\begin{array}{l}4 \cdot 35 \\
3 \cdot 97 \\
3 \cdot 54 \\
2 \cdot 81 \\
2 \cdot 47\end{array}$ & $\begin{array}{r}6 \\
16 \\
21 \\
24 \\
34\end{array}$ & $\begin{array}{l}4 \cdot 01 \\
3.97 \\
3.67 \\
3.00 \\
2.64\end{array}$ & $\begin{array}{l}P>0.80 \\
P>0.25 \\
P>0.90 \\
P<0.001 \\
0.02>P>0.01\end{array}$ \\
\hline All ages & 160 & $3 \cdot 64$ & 143 & $3 \cdot 25$ & 88 & $3 \cdot 67$ & 273 & 3.51 & 150 & $3 \cdot 30$ & 511 & $3 \cdot 48$ & IOI & $3 \cdot 23$ & \\
\hline
\end{tabular}

was slightly higher in smokers and ex-smokers than in non-smokers. There was little difference in the prevalence of chest illness during the past three years between any of the groups. The high prevalence of breathlessness in ex-smokers is presumably attributable to the fact that this symptom may lead a man to give up smoking.

The mean values for forced expiratory volume are shown in Table IX and Figs $I$ and 2 according to age and smoking habits. There is little difference between smokers and non-smokers under 50 years of age. In each of the two oldest age groups, 50-59 and 60-69, cigarette smokers and ex-smokers recorded a lower mean F.E.V $\cdot \cdot_{1.0}$ than non-smokers. Consistently higher average values were observed in light smokers than in moderate and heavy smokers over the age of 30 years. No consistent differences were apparent in the mean values for those who said they inhaled compared with those who said they did not. The numbers of the non-inhalers were, however, small.

Education Level, Respiratory Symptoms, and F.E.V. An association between respiratory symptoms and F.E.V. and educational attainment was shown by Enterline and Lainhart (1967) in their studies of mining communities in southern West Virginia. Information on education was also obtained in this survey. People were classified, on the basis of the highest grade achieved, into three groups: (I) those who had completed 8 grades or less, (2) those with 9 to 12 grades, and (3) those who had completed one or more years in college. The prevalence of symptoms was fairly closely correlated with educational level. There was a higher prevalence of all symptoms in the less educated (Table X). There also appeared to be a consistent trend in F.E.V. with education (Table XI and Fig. 3). In 


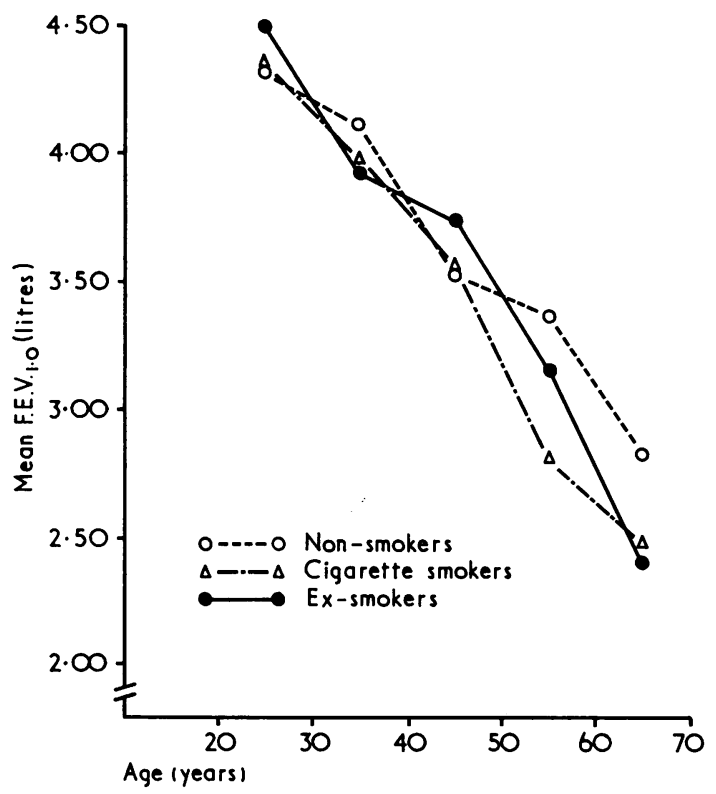

FIG. I. Mean F.E.V.1.0 by age and smoking in white men aged 20-69 in three towns in Marion County, West Virginia.

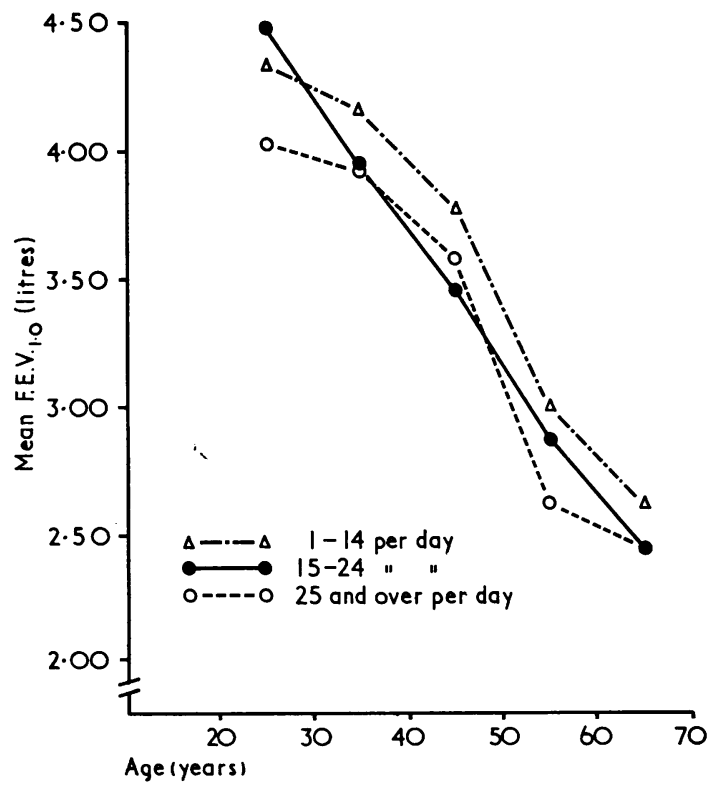

FIG. 2. Mean F.E.V.1.0 by age and smoking (number of cigarettes/day) in white men aged 20-69 in three towns in Marion County, West Virginia.

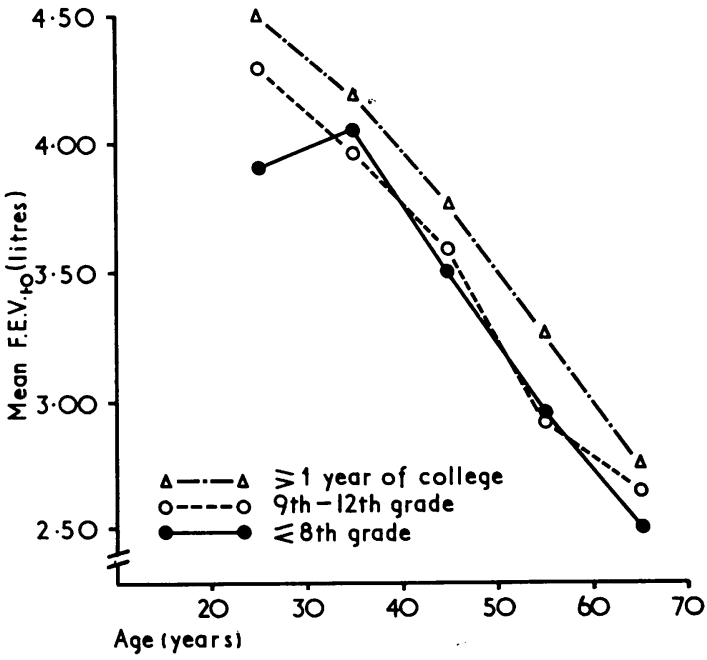

FIG. 3. Mean F.E.V.1.0 by age and education in white men aged 20-69 in three towns in Marion County, West Virginia.

each decennial group the mean F.E.V. was higher in those men who had had one year or more in college. Differences in height between the groups can explain only a small amount of these differences. Small contributions to the observed differences may be accounted for by relationships between education and occupation, smoking habits, and ability to understand and perform the lung function test.

\section{Discussion}

\section{Comparison of Findings in this Study with those in Other Surveys}

Prevalence of Pneumoconiosis The prevalence of pneumoconiosis observed in this study among miners and ex-miners who had not worked in the pottery is similar to that found by Lieben and McBride (1963) in their study of pneumoconiosis in bituminous coal miners in Western Pennsylvania. It is lower than that found in Appalachian coal mining areas by the U.S. Public Health Service (McClure, personal communication). In the survey carried out by the Public Health Service in Mullens, southern West Virginia, some degree of pneumoconiosis was found in $20 \%$ of men aged $21-64$ (Enterline, 1967) but this figure includes suspect cases, and the more comparable figure is $13.5 \%$ for definite cases. This is higher than the $7.5 \%$ we 
TABLE $X$

Prevalence of Respiratory Symptoms by Educational Attainment IN White MEN Aged 20-69 IN Three TOWNS IN WESTERN VIRGINIA (Age-Adjusted Percentages)

\begin{tabular}{|c|c|c|c|c|}
\hline Symptom & $\begin{array}{c}\leqslant \\
\text { Grade } \\
8 \\
(297)\end{array}$ & $\begin{array}{c}\text { Grade } \\
9-I 2 \\
(487)\end{array}$ & $\begin{array}{c}\text { I year } \\
\text { or more } \\
\text { in } \\
\text { College } \\
\text { (I2I) }\end{array}$ & $\begin{array}{l}\text { I Year College } \\
\text { compared with } \\
\text { Grade I to I } 2\end{array}$ \\
\hline $\begin{array}{l}\text { Cough } \quad \cdots \\
\text { Sputum } \ldots \\
\text { Cough and sputum } \\
\text { Chest illness } \\
\text { Breathlessness } \quad \ldots \\
\text { Chronic bronchitis }\end{array}$ & $\begin{array}{l}33 \cdot 4 \\
33 \cdot 4 \\
23 \cdot 3 \\
12 \cdot 2 \\
25 \cdot 1 \\
6 \cdot 4\end{array}$ & $\begin{array}{r}32 \cdot 1 \\
29 \cdot 4 \\
20 \cdot 3 \\
13 \cdot 5 \\
10 \cdot 8 \\
5 \cdot 2\end{array}$ & $\begin{array}{r}24 \cdot 1 \\
28 \cdot 1 \\
18 \cdot 7 \\
10 \cdot 6 \\
13 \cdot 5 \\
7 \cdot 6\end{array}$ & $\begin{array}{l}P<0.001 \\
P=0.05 \\
0.05>P>0.01 \\
0.05>P>0.01 \\
0.05>P>0.01 \\
P<0.01\end{array}$ \\
\hline
\end{tabular}

Numbers in parentheses

found, and it would therefore appear that pneumoconiosis may be less prevalent in the north than in the south of the state.

The prevalence of pneumoconiosis in our survey is much lower than that found in mining communities in Great Britain (Table XII). The largest contrast is with the Rhondda in Wales, the smallest with Leigh in England. In both these areas P.M.F., in particular, occurred much more often than in northern West Virginia.

Prevalence of Respiratory Symptoms and Ventilatory Lung Function The prevalence of persistent cough and sputum in the present survey was similar to that found in the more recent British surveys (Higgins and Cochrane, 196r). Changes in the precise wording of the questions makes comparison with the earlier studies less reliable. The prevalence of reported breathlessness was slightly higher in the present survey than in the British ones. This is probably more a reflection of differences in activity patterns and body weight than of differences in respiratory disability. On the average, men in West Virginia weighed about $17 \mathrm{lb}$. $(7 \cdot 7 \mathrm{~kg}$.) more than men of the same age in Wales. The prevalence of chest illness during the three

TABLE XI

Mean F.E.V.1.0 (litres) by Age and Education in White Men in Three Towns in Marion County, WEST VIRGINIA

\begin{tabular}{|c|c|c|c|c|c|c|c|c|c|}
\hline \multirow[t]{2}{*}{ Age } & \multicolumn{2}{|c|}{$\leq$ Grade 8} & \multicolumn{2}{|c|}{ Grade 9-I 2} & \multicolumn{2}{|c|}{$\begin{array}{c}\text { I Year or more in } \\
\text { College }\end{array}$} & \multicolumn{2}{|c|}{$\begin{array}{c}\text { Total } \\
\text { Education Known }\end{array}$} & \multirow{2}{*}{$\begin{array}{c}\text { I Year or more in } \\
\text { College compared with } \\
\text { Grades I to II }\end{array}$} \\
\hline & $N o$ & Mean & $N o$ & Mean & No. & Mean & $N o$ & Mean & \\
\hline $\begin{array}{l}20- \\
30- \\
40- \\
50- \\
60-\end{array}$ & $\begin{array}{r}10 \\
25 \\
64 \\
107 \\
91\end{array}$ & $\begin{array}{l}3 \cdot 89 \\
4 \cdot 05 \\
3 \cdot 51 \\
2 \cdot 95 \\
2 \cdot 51\end{array}$ & $\begin{array}{r}89 \\
119 \\
128 \\
103 \\
48\end{array}$ & $\begin{array}{l}4 \cdot 31 \\
3 \cdot 95 \\
3 \cdot 59 \\
2 \cdot 92 \\
2 \cdot 65\end{array}$ & $\begin{array}{l}45 \\
20 \\
21 \\
24 \\
\text { I I }\end{array}$ & $\begin{array}{l}4 \cdot 49 \\
4 \cdot 19 \\
3 \cdot 75 \\
3 \cdot 24 \\
2 \cdot 74\end{array}$ & $\begin{array}{l}144 \\
164 \\
213 \\
234 \\
150\end{array}$ & $\begin{array}{l}4 \cdot 34 \\
3 \cdot 99 \\
3 \cdot 58 \\
2 \cdot 97 \\
2 \cdot 57\end{array}$ & $\begin{array}{r}0.10>P>0.05 \\
0.15>P>0.10 \\
0.20>P>0.10 \\
0.05>P>0.02 \\
P>0.40\end{array}$ \\
\hline All ages & 297 & 3.06 & 487 & $3 \cdot 58$ & I2I & $3 \cdot 91$ & 905 & $3 \cdot 45$ & \\
\hline
\end{tabular}

TABLE XII

Comparison of Pneumoconiosis Prevalence in Miners and Ex-miners in Different Communities

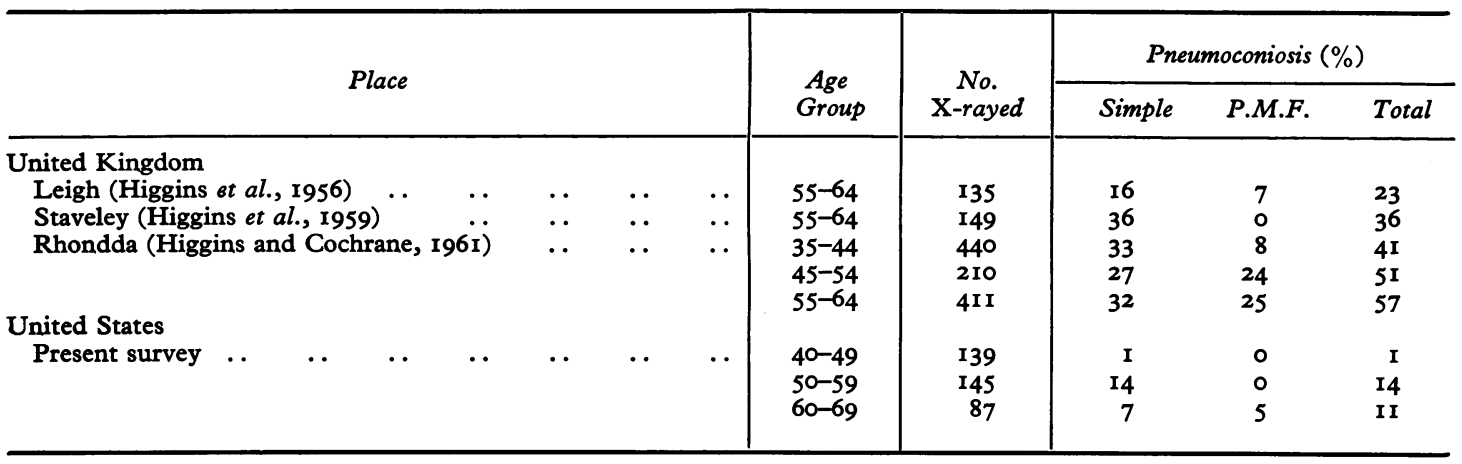




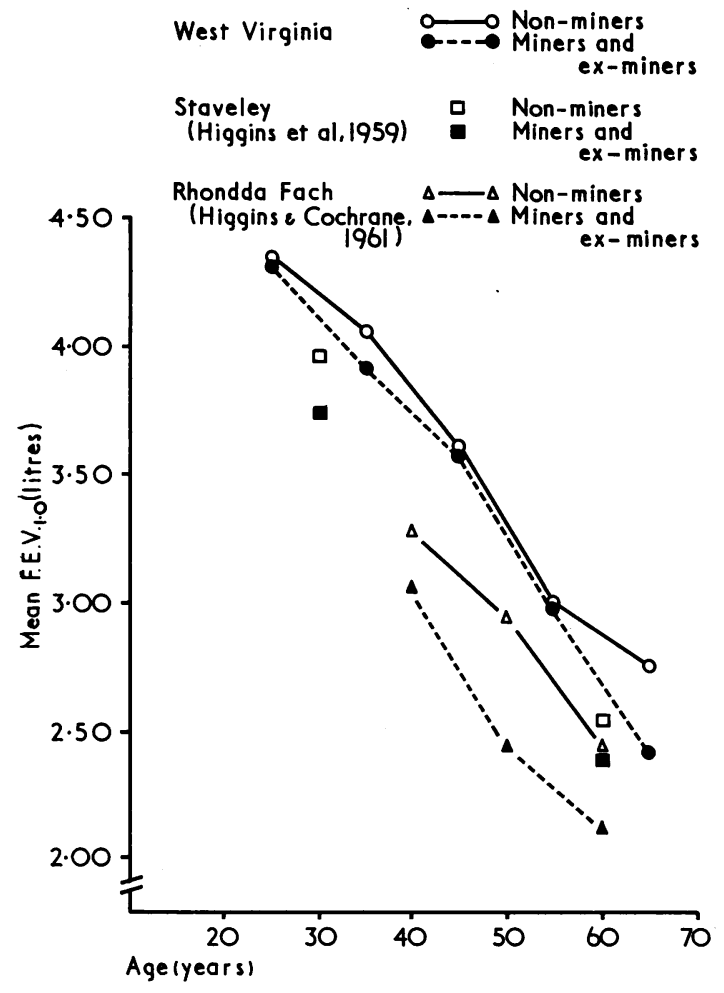

Fig. 4. Mean F.E.V.1.0 by age, occupation, and area in white men in three towns in Marion County, West Virginia and in three areas in the U.K.

years preceding interview was lower in West Virginia than in Britain, particularly recurrent episodes.

Comparison of the F.E.V. in three towns in West Virginia and in several surveys carried out by the British Medical Research Council's Pneumoconiosis Research Unit using similar methods (Higgins and Cochrane, 1961) is shown in Figure 4. The mean values at all ages were significantly lower in the British studies for both miners and nonminers. This difference is partly due to a difference in height between British and American survey participants (Fig. 5). But even when this is allowed for, the mean F.E.V. was higher in the population of West Virginia.

These findings are consistent with the observation that the prevalence of mild respiratory symptoms and disease is similar in the two countries whereas serious disability and mortality are more common in the United Kingdom (Reid, Anderson, Ferris, and Fletcher, 1964). Further consideration is being given to international and national comparisons in an attempt to elucidate the role of factors such as smoking habits, climate, and air pollution.

The present findings are also consistent with the earlier findings in Britain that miners and ex-miners have a higher prevalence of respiratory symptoms and lower ventilatory function than non-miners; but the differences are small. Thus, in the 50-69 age group, the prevalence of persistent cough and sputum and of a chest illness during the past three years was slightly higher in the miners and exminers than in the non-miners. The prevalence of moderate breathlessness was also higher but only in the 60-69 age group. The mean F.E.V. was almost the same for the two occupational groups in each decennial age group from 20 to 59 . Only in the 60-69 age group did the miners record a lower average value than the non-miners. This suggests that the concentration of dust encountered in the mines in these West Virginia towns nowadays has little effect on either respiratory symptoms or lung function.

The findings with regard to the effect of exposure to pottery dust are inconsistent. In both mining and non-mining groups a slightly higher prevalence of cough and sputum was noted in those without pottery experience than in those with. Men exposed to pottery dust did, however, have a higher prevalence of moderate breathlessness and of chest illness. The lower average F.E.V. in the nonminers aged $60-69$ with pottery experience is

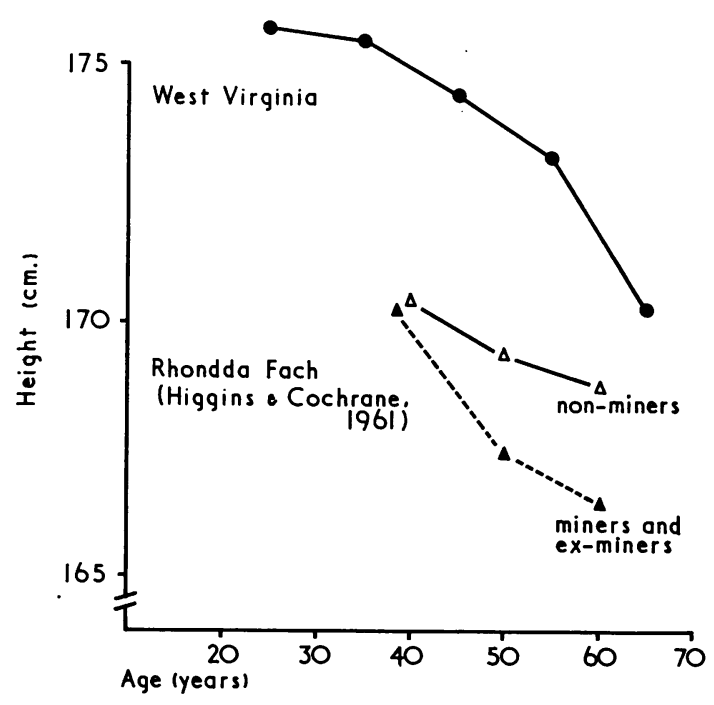

FIG. 5. Mean standing height by age in white men in three towns in Marion County, West Virginia and in Rhondda Fach, U.K. 
consistent with the difference in the prevalence of breathlessness. But in the miners and ex-miners the differences in mean F.E.V. which were observed were in the opposite direction, being lower in the men who had not been exposed to pottery dust. The discrepancy may be due to the small numbers of miners and ex-miners who had worked in pottery or to shorter exposures to dust among men who had changed jobs.

The lack of any consistent relationship between either symptom prevalence or mean F.E.V. and the duration of dusty work, estimated from the number of years of underground work, is in line with findings in Britain. In their survey in the Rhondda, Higgins and Cochrane (I96I) found a somewhat higher prevalence of symptoms in men aged 35-64 who had worked for one year or more on the coalgetting shift than in those who had worked for less than one year. In the 55-64 age group those with one year or more on the coal-getting shift also had a correspondingly lower mean F.E.V. But after the first year there appeared to be no consistent trend in F.E.V. with increasing lifetime dust dosage. Two explanations of the findings seemed possible: either there is no close relation between dust dosage and prevalence of symptoms or mean F.E.V., or a relationship is concealed by selection of the groups whereby only those who are fit enough remain at work on the face for many years while the others change to less dusty jobs underground or leave mining.

Comparison with Studies in South African Goldminers Sluis-Cremer and his colleagues (Sluis-Cremer, Walters, and Sichel, 1967a, 1967b) have recently published their findings on a random sample of goldminers and non-miners. Chronic bronchitis was significantly more common in miners than in non-miners for every age and smoking group except non-smokers; but there was no significant difference in ventilatory capacity between them other than that due to the excess of chronic bronchitis in the miners. These authors conclude that dust exposure has no effect on ventilatory capacity over and above the role it may have in causing chronic bronchitis. It appears from our study that dust exposure to the bituminous coal, in the concentrations now present in the mines included in our survey, has little effect on symptoms or on ventilatory capacity though it may have had such an effect in the past. This conclusion should not, however, be extrapolated to other mining areas in the United States where conditions may well be very different.

It is impossible to mention by name all those who contributed to the success of this survey. We should, however, like to express our thanks to the late Dr. Guy Post, Director of the Marion- County Health Department, to Dr. M. Hunter, Medical Director, and Mr. M. Ross, Administrator, of the Fairmont Clinic; to the members of the field survey team, especially Mrs. Jane Kasgard, Home Interviewer; and to our colleagues at the Graduate School of Public Health, University of Pittsburgh. We should also like to thank Dr. Anthony M. Schork, Department of Biostatistics, School of Public Health, University of Michigan, Ann Arbor, for statistical assistance.

This work was carried out under U.S.P.H.S. Contract P.H. 86-64-89 from the Division of Occupational Health.

The use of the University Computer Center, partially supported by NSF Grant Gir309, is gratefully acknowledged.

\section{REFERENCES}

Blackburn, H., Keys, A., Simonson, E., Rautaharju, P., and Punsar, S. (1960). The electrocardiogram in population studies. A classification study. Circulation, 21, I160.

Densen, P. M., Brewer, J., Bass, H. E., and Jones, E. W. (1966). Chronic respiratory disease in two employed male populations in New York City. Tech. Rep. to Div. Occup. Hlth. Publ. Hlth. Service, U.S. Dept. Hlth. Educ. and Welf. Dec.

Dorn, H. F. (196I). The increasing mortality from chronic respiratory diseases. Proc. Soc. Stat. Sect. Amer. Stat. Assoc. pp. 148-152.

Enterline, P. E. (1966). Mortality rates among coal miners. Amer. F. publ. Hlth, 54, 758.

- (1967). The effects of occupation on chronic respiratory disease. Arch. environm. Hlth, 14, 189.

-, and Lainhart, W. S. (1967). The relationship between coal mining and chronic non-specific respiratory disease. Amer. F. publ. Hlth, 57, 484.

Higgins, I. T. T., and Cochrane, A. L. (196I). Chronic respiratory disease in a random sample of men and women in Rhondda Fach in 1958. Brit. F. industr. Med., 18, 93-102.

,,-- Gilson, J. C., and Wood, C. H. (1959). Population studies of chronic respiratory disease. A comparison of miners, foundryworkers, and others in Staveley, Derbyshire. Ibid., 16, 255-268.

- , and Oldham, P. D. (1962). Ventilatory capacity in miners. A five-year follow-up study. Brit. $\mathcal{f}$. industr. Med., 19, 65-76.

$\longrightarrow,-$, Cochrane, A. L., and Gilson, J. C. (1956). Respiratory symptoms and pulmonary disability in an industrial town. Brit. med. F., 2, 904.

International Classification of Persistent Radiological Capacities in the Lung Fields Provoked by the Inhalation of Mineral Dusts. (1958). International Labour Office, Geneva, Switzerland.

Lieben, J., and McBride, W. W. (1963). Pneumoconiosis in Pennsylvania's bituminous mining industry. F. Amer. med. Ass., 183, 176.

McKerrow, C. B., McDermott, M., and Gilson, J. C. (1960). A spirometer for measuring the forced expiratory volume with a simple calibrating device. Lancet I, I49.

Merrill, M. H. (1963). Public health responsibilities and program possibilities in chronic respiratory diseases. Amer. F. Publ. Hlth, 53, no. 3 (pt. 2), p. 25. (Suppl.) 
Moriyama, I. M. (1963). Chronic respiratory disease mortality in the United States. Publ. Hlth. Rep. (Wash.), 78, 743.

Registrar General's Decennial Supplement-England and Wales, 195I (1958). Occupational Mortality Part II. H.M.S.O., London.

Registrar General's Statistical Review of England and Wales for 1963 (1965). Part I Tables, Medical. H.M.S.O., London.

Reid, D. D., Anderson, D. O., Ferris, B. G., and Fletcher, C. M. (1964). An Anglo-American comparison of the prevalence of bronchitis. Brit. med. f., 2, 1487.

Sluis-Cremer, G. K., Walters, L. G., and Sichel, H. S. (1967a). Chronic bronchitis in miners and non-miners: An epidemiological survey of a community in the goldmining area of the Transvaal. Brit. f. industr. Med., 24 I-12.

- - $(1967 \mathrm{~b})$. Ventilatory function in relation to mining experience and smoking in a random sample of miners and non-miners in a Witwatersrand town. Ibid., 24, 13-25.

U.S. Department of Health and Educational Welfare. (1963). Mortality by occupation level and cause of death among men 20-64 years of age U.S., 1950 Vital Statistics Special Reports, 53, 5 (Sept.).

- Vital Statistics of the U.S. Mortality (annual publication) Washington D.C. Government Printing Office.

World Health Organization (1963). Epidemiological and Vital Statistics Report. 